\title{
Characterization of thermostable aminoacylase from Geobacillus sp. strain SZN
}

\author{
Suzana Adenan ${ }^{\mathrm{a}}$, Chee Fah Wong ${ }^{\mathrm{a}^{*}}$, Haniza Hanim Mohd Zainª Saripah Salbiah Syed Abdul Azziz ${ }^{\mathrm{b}}$, \\ Raja Noor Zaliha Raja Abd. Rahman ${ }^{c}$
}

\begin{abstract}
${ }^{a}$ Department of Biology, Faculty of Science and Mathematics, Universiti Pendidikean Sultan ldris, 35900 Tanjong Malim, Perak, Malaysia ${ }^{b}$ Department of Chemistry, Faculty of Science and Mathematics, Universiti Pendidikan Sultan ldris, 35900 Tanjong Malim, Perak, Malaysia 'Department of Microbiology, Faculty of Biotechnology and Biomolecular Sciences, Universiti Putra Malaysia, 43400 Serdang, Selangor, Malaysia
\end{abstract}

Received 21st February 2019 / Accepted 11th July 2019

\begin{abstract}
Aminoacylase (EC 3.5.1.14) hydrolyzes N-acetylated amino acids to produce amino acids. Although thermostable aminoacylase has been commercially produced since 2004, there was a knowledge gap in the field of understanding aminoacylase thermostability from a structural point of view. This study investigated the physical and structural properties of the purified thermostable aminoacylase SZN. The spectropolarimetry data for structural determination has indicated a gradual decrease of $\alpha$-helix from 36 to $27.6 \%$, followed by tremendous disorientation of the structure at the transition of temperatures from 60 to $70^{\circ} \mathrm{C}(27.6$ to $19.5 \%)$. In contrast, the percentage of $\beta$-sheet has increased steadily over the tested temperatures. The $\alpha$-helix, where notable metal binding and catalytic residues are located, was totally weakened at temperatures above $70^{\circ} \mathrm{C}$, thus resulted in loss of activity. The loss of the $\alpha$-helical structure could further explain drastic deterioration of activity at temperatures beyond $70^{\circ} \mathrm{C}$. The activity of aminoacylase SZN was enhanced by divalent metal ions, such as $\mathrm{Mn}^{2+}$ and $\mathrm{Cu}^{2+}$, and inhibited by detergent Triton-X-100. As a conclusion, the isolated aminoacylase SZN was characterized as a thermostable enzyme based on the $\alpha$-helical structure integrity and functional stability in high temperatures. This enzyme could be used as an alternative enzyme for bioindustries in view of its activity enhancement in high temperatures and stability in various tested inhibitors.
\end{abstract}

Keywords: aminoacylase; Geobacillus sp.; secondary structure; thermostable enzyme; $\alpha$-helix

\section{INTRODUCTION}

Global amino acid market demand was 7.5 million tons in 2016 and was expected to reach a volume of more than 10 million tons in 2020 (Research \& Market, 2015). The market of amino acids is anticipated to reach USD 30.8 billion by the end of 2024. This can be attributed to various factors such as growing consumer awareness and the rising demand for healthy and functional foods. The search for new local thermostable aminoacylase is needed in the global industry, especially in the industry that focusing on productions of amino acids. Enzymes from extremophiles are more attractive compared to other common enzymes because they can perform industrial processes even under harsh conditions, under which common proteins are completely denatured. In common cells, enzymes will be denatured and unfolded when the

*Author for correspondence: Chee Fah Wong, Department of Biology, Faculty of Science and Mathematics, Universiti Pendidikan Sultan Idris, 35900 Tanjong Malim, Perak, Malaysia. Email - cheefah@fsmt.upsi.edu.my. 
temperature increased beyond a specific point. The rate of molecular movement and reaction increased when the temperature increased, but at the same time, there is a progressive inactivation caused by denaturation of the enzyme protein (Robinson, 2015). This is because the threedimensional structures of proteins are damaged resulted from breakage of hydrogen and disulphide bonds that are responsible to maintain the enzyme structure. Protein unfolding may cause the enzyme unable to catalyze the reactions appropriately because it had lost its fundamental shape which is associated with its specific affinity and its substrate binding site. This work was emphasized on studying thermostable aminoacylase SZN secondary structure stability and its distortion at high temperatures. Furthermore, providing a better understanding of the adaptation of thermostable aminoacylase at high temperatures, from the structural point of view is our subsequent objective.

\section{MATERIALS AND METHODS}

\section{Source of bacterium}

The water samples $\left(59^{\circ} \mathrm{C}\right)$ were collected from Ulu Slim Hot spring in Perak (GPS coordinate: $\left.3.8988^{\circ} \mathrm{N}, 101.4979^{\circ} \mathrm{E}\right)$. A thermophile from Geobacillus species, identified as a new strain known as strain SZN, was isolated (Adenan et al., 2018), and the aminoacylase extracted from the bacteria cells was applied throughout this work to study its biochemical properties and characteristics.

\section{Aminoacylase assay}

Aminoacylase activity was determined in $0.5 \mathrm{~mL}$ assay mixtures containing $0.2 \mathrm{~mL}$ of aminoacylase enzyme in $50 \mathrm{mM}$ Tris- $\mathrm{HCl}(\mathrm{pH} 7.5)$ and $0.3 \mathrm{~mL}$ of $10 \mathrm{mM}$ of $\mathrm{N}$-acetyl-L-methionine (NAMET) substrate. The $0.5 \mathrm{~mL}$ assay mixtures were shaken for $30 \mathrm{~min}$ with shaking at $200 \mathrm{rpm}, 60^{\circ} \mathrm{C}$. The reaction was stopped using $0.5 \mathrm{~mL}$ of $10 \%$ trichloroacetic acid. The precipitated protein was removed by centrifugation method with $4000 \mathrm{rpm}$ for $1 \mathrm{~min}$. Then, $1 \mathrm{~mL}$ supernatant was mixed with $0.25 \mathrm{~mL}$ of $3 \%$ ninhydrin solution and 0.25 $\mathrm{mL}$ of $250 \mathrm{mM}$ acetic-cyanide (pH5.0) buffer. The mixture was boiled for $15 \mathrm{~min}$ and cooled to ambient temperature by the addition of $1.5 \mathrm{~mL}$ of $50 \% \quad(\mathrm{v} / \mathrm{v})$ isopropanol. The liberated Lmethionine was measured using Biomate $3 \mathrm{~S} \mathrm{UV}$ visible spectrophotometer (Thermo Fisher Scientific, USA) at absorbance wavelenghth of $570 \mathrm{~nm}\left(\mathrm{~A}_{570}\right)$. L-methionine amount was determined from standard curve that was prepared according to Moore and Stein (1948).

\section{Preparation of cell extract}

The crude cell extract for the assay was prepared from $1 \mathrm{~L}$ of the culture growth at $60^{\circ} \mathrm{C}$ overnight in $\mathrm{LB}$ broth. The supernatant of the culture was removed by centrifugation at $12,000 \mathrm{rpm}$ and $4^{\circ} \mathrm{C}$ for $10 \mathrm{~min}$. The precipitated cells were washed with $50 \mathrm{mM}$ Tris-HCl ( $\mathrm{pH} 7.5)$. The cells were then resuspended in $50 \mathrm{~mL}$ of $50 \mathrm{mM}$ Tris- $\mathrm{HCl}$ $(\mathrm{pH} 7.5)$ and disrupted by using ultrasonic disruptor UD-200 at $60 \mathrm{~W}$ for $4 \mathrm{~min}$ intermittently in an ice bath. Cell extract was obtained by centrifugation at $12,000 \mathrm{rpm}$ for 10 min at $4^{\circ} \mathrm{C}$. The cell extract was subjected to aminoacylase assay at a different range of temperatures $\left(30,40,50,60,70,80\right.$, and $\left.90^{\circ} \mathrm{C}\right)$ for characterization, and at $60^{\circ} \mathrm{C}$ for standard assay.

\section{Aminoacylase purification steps}

Ion exchange chromatography (IEX)

A flow rate of $0.7 \mathrm{~mL} / \mathrm{min}$ was used during crude enzyme sample injection into XK16 column containing $10 \mathrm{~mL}$ of DEAE-Sepharose Fast Flow resin (GE Healthcare, Sweden). Prior to sample injection, the resin was pre-equilibrated with 50 $\mathrm{mM}$ Tris- $\mathrm{HCl}$ ( $\mathrm{pH} 7.5)$, as the binding buffer. The column was then washed with 10 column volumes (cv) of the binding buffer followed by ascending linear gradient elution with $25 \mathrm{cv}$ of $\mathrm{NaCl}$ varying from 0 to $1.0 \mathrm{M}$. Eluate size was set at $2.0 \mathrm{~mL}$ per fraction, in which all fractions were subjected to aminoacylase assay and dodecyl sulfate polyacrylamide gel electrophoresis (SDS-PAGE) to observe the protein size and enzyme purity. Fractions with high enzyme activity and less contaminants (unwanted proteins) were pooled and subjected to gel filtration purification step by using Sephacryl (S-200) HR resin (GE Healthcare, Sweden).

\section{Gel filtration chromatography}

The fractions from IEX with high aminoacylase activity were pooled and concentrated up to $0.8 \%$ 
of the total column volume ( $80 \mathrm{~mL}$ resin) by using molecular weight cut-off spin column $(10.0 \mathrm{kDa})$ (Milipore, USA) at $10,000 \mathrm{rpm}, 4^{\circ} \mathrm{C}$. The concentrated sample was then loaded into S-200 column with flow rate $0.2 \mathrm{~mL} / \mathrm{min}$ using the peristaltic pump. The sample was eluted using 50 $\mathrm{mM}$ Tris-HCl (pH 7.5) buffer. Eluate size was set at $1.0 \mathrm{~mL}$ per fraction, in which all fractions were subjected to aminoacylase assay and SDS-PAGE to observe the protein size and purity. The protein content was determined by the Bradford (1976) method using the Bio-Rad assay reagent and Bovine serum albumin as the standard. The protein concentration from each step of purification was monitored by measuring their absorbance at $280 \mathrm{~nm}$.

\section{Thermal characterization of aminoacylase $S Z N$}

Assessment of aminoacylase secondary structure stability by circular dichroism (cd)

Mechanisms of protein stability in various temperatures were analyzed using JASCO J-810 Circular Dichroism Spectropolarimeter (Tokyo, Japan). By utilizing several parameters preprogrammed in Spectra Manager software (JASCO, Japan), the generated CD spectra can be used for analysis in secondary structure changes as well as thermal denaturation. Secondary structures estimation was determined by CD spectra obtained at wavelength $190-240 \mathrm{~nm}$. The enzyme sample was transferred into a completely closed $10.0 \mathrm{~mm}$ cell containing $1.0 \mathrm{mg} / \mathrm{mL}$ native enzyme solutions, which was heated at 10, 20, 30, $40,50,60,70,80,90$, and $100^{\circ} \mathrm{C}$ at $1{ }^{\circ} \mathrm{C} / \mathrm{min}$ heating rate. Data pitch, bandwidth, response and scanning speed were programmed as 0.1 degree, 1 $\mathrm{nm}, 8$ seconds and 1 degree per minute.

\section{Thermal denaturation analysis}

The measurement of thermal denaturation $\left(T_{\mathrm{m}}\right)$ was acquired from ellipticity at $222 \mathrm{~nm}$ of a completely closed $10.0 \mathrm{~mm}$ cell containing 1.0 $\mathrm{mg} / \mathrm{mL}$ native enzyme solutions, which was heated at 10, $20,30,40,50,60,70,80,90$, and $100^{\circ} \mathrm{C}$ with $1{ }^{\circ} \mathrm{C} / \mathrm{min}$ heating rate. Data pitch, bandwidth, response, and scanning speed were programmed as 0.1 degree, $1 \mathrm{~nm}, 8$ seconds and 1 degree per minute, respectively. $T_{\mathrm{m}}$ is determined at the midpoint of sigmoidal melting curves.

\section{Effect of temperature on aminoacylase activity}

Investigation on hydrolysis of $N$-acetyl-LMethionine (NAMET) by aminoacylase SZN at temperatures $30,40,50,60,70,80$, and $90^{\circ} \mathrm{C}$ was conducted at a shaking rate of $200 \mathrm{rpm}$ for $30 \mathrm{~min}$. Aminoacylase activities that exhibited in various temperatures were compared in relative to activity at $60^{\circ} \mathrm{C}$ that served as control $(100 \%)$.

\section{Effect of temperature on ensyme stability}

Pre-incubation of the enzyme in temperatures of $5,20,30,40,50,60,70,80,90$ and $100^{\circ} \mathrm{C}$ for 30 min in $200 \mathrm{rpm}$ water bath shaker was carried out prior to aminoacylase assay, in order to determine the enzyme temperature stability. Activity at $5^{\circ} \mathrm{C}$ was selected as a standard (100\%).

Effect of exposure time at $60^{\circ} \mathrm{C}$ on aminoacylase $S Z N$ The half-life of the enzyme was examined by preincubating the protein at $60^{\circ} \mathrm{C}$ from $0-36$ hours in a water bath shaker. Samples were removed at intervals of $4 \mathrm{~h}$ for measurement of activity, in which the activity at $0 \mathrm{~min}$ is a control $(100 \%)$ of the experiment.

\section{Other characterization of thermostable aminoacylase $S Z N$}

Effect of $p H$ on aminoacylase activity and stability

The optimum $\mathrm{pH}$ of aminoacylase SZN activity was determined by the enzymatic hydrolysis of NAMET in $50 \mathrm{mM}$ of different buffers. The buffering systems used were sodium acetate $(\mathrm{pH}$ 4, $\mathrm{pH} 5, \mathrm{pH} 6)$, potassium phosphate ( $\mathrm{pH} 6, \mathrm{pH}$ 7, $\mathrm{pH} 8)$, Tris- $\mathrm{Cl}(\mathrm{pH} 8, \mathrm{pH} 9)$, sodium tetraborate $(\mathrm{pH} 9, \mathrm{pH} 10, \mathrm{pH} 11)$, and sodium hydrogen phosphate $(\mathrm{pH} 11, \mathrm{pH} 12)$. The substrate was resuspended with buffers at various $\mathrm{pHs}$ with ratio $1: 3(\mathrm{v} / \mathrm{v})$. For $\mathrm{pH}$ stability test, aminoacylase was pre-incubated with buffers of tested $\mathrm{pHs}$ at ratio of $1: 3(\mathrm{v} / \mathrm{v})$ at $60^{\circ} \mathrm{C}$ and $200 \mathrm{rpm}$ for $30 \mathrm{~min}$ followed by enzyme assay. Enzyme activity in 50 $\mathrm{mM}$ phosphate buffer ( $\mathrm{pH}$ 8.0) was further chosen as control for this experiment.

\section{Effect of metal ions on aminoacylase activity}

In this study, the enzyme was pre-treated with 0 , 1.0 and $10.0 \mathrm{mM}$ of chloride $\left(\mathrm{Cl}^{-}\right)$metal ions, such as $\mathrm{Na}^{+}, \mathrm{K}^{+}, \mathrm{Mg}^{2+}, \mathrm{Ca}^{2+}, \mathrm{Mn}^{2+}, \mathrm{Co}^{2+}, \mathrm{Ni}^{2+}, \mathrm{Cu}^{2+}$ and $\mathrm{Zn}^{2+}$ for $30 \mathrm{~min}$ at $60^{\circ} \mathrm{C}$ before subjected to enzyme assay. 
Effect of inbibitors on aminoacylase activity

Denaturing and reducing agents, such as $\beta$ mercapthoethanol, Triton-X-100, Tween 20, sodium dodecyl sulphate (SDS) and dithiothreitol (DTT), phenylmethylsulfonyl fluoride (PMSF), ethylenediaminetetraacetic acid (EDTA), were used at final concentrations of 5.0 and $10.0 \mathrm{mM}$ to treat the protein at $60^{\circ} \mathrm{C}$ for $30 \mathrm{~min}$. Inhibitorfree mixture was considered to be the negative control in the colorimetric assay.

\section{RESULTS}

\section{Purification of aminoacylase from Geobacillus sp. strain SZN}

Aminoacylase SZN was successfully purified using Ion Exchange DEAE Sepharose Fast Flow chromatography (IEX) (Figure 1) and Sephacryl S-200 Gel Filtration chromatography (GF) (Figure 2). The purification results are summarized in Table 1. The enzyme purity was obtained at 14.04 fold, compared to crude, with final yield at $16.53 \%$ utilizing only two steps of chromatography, caused its specific activity of the purified enzyme increased to $66.4 \mathrm{U} / \mathrm{mg}$ at the final step compared to specific activity from crude which was $4.73 \mathrm{U} / \mathrm{mg}$. The protein sample from each purification step was analyzed by SDSPAGE and the purity of aminoacylase SZN from each purification step can be observed in Figure 3 , shows that the purified protein was resolved almost as single band at $\sim 42 \mathrm{kDa}$.

\section{Characterization of aminoacylase strain SZN} Assessment of aminoacylase secondary structure stability by $C D$

The protein stability in various temperatures $(10$, $20,30,40,50,60,70,80,90$ and $100^{\circ} \mathrm{C}$ ) was analyzed using JASCO J-810 CD Spectropolarimeter (Figure 4) and estimated the percentage of $\alpha$-helix and $\beta$-sheet secondary structures by using Perry Freeshell server (Raussens et al., 2003) (Table 2). The results showed that the $\alpha$-helix was still maintained its original structure even heated up to $60^{\circ} \mathrm{C}$. At 10 $40^{\circ} \mathrm{C}$, the percentages of $\alpha$-helix and $\beta$-sheet were maintained in a range of $34-37 \%$ and $16-19 \%$, respectively. The $\alpha$-helix was appeared at $28-32 \%$ and $\beta$-sheet at $19-23 \%$ when temperatures increased to $50-60^{\circ} \mathrm{C}$. At $100^{\circ} \mathrm{C}$, aminoacylase SZN significantly lost its $\alpha$-helical conformation and changed to $\beta$-sheet as each of the conformation was recorded at $12 \%$ and $33 \%$, respectively.

$1 \mathrm{M} \mathrm{NaCl}$

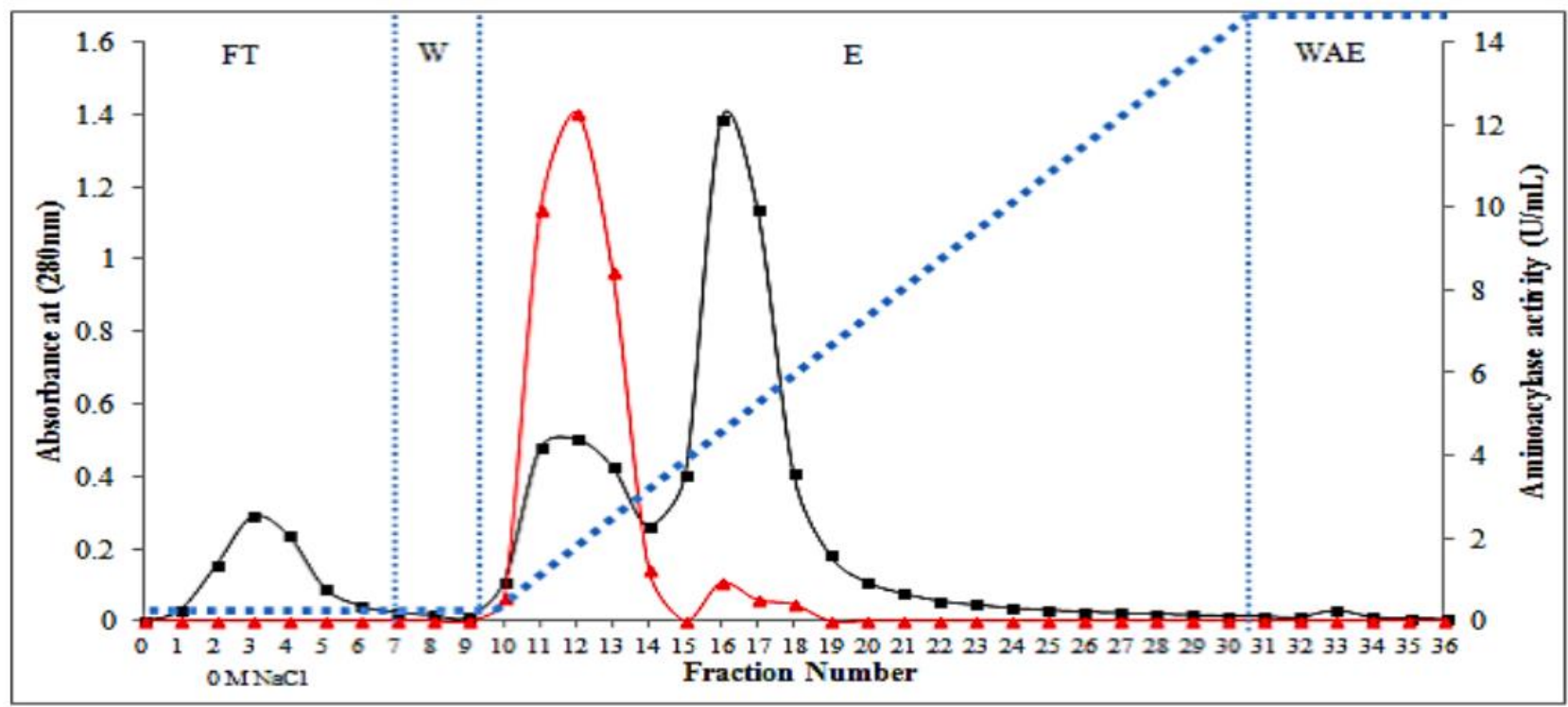

Figure 1. Ion-Exchange Column Chromatography of cell extracts from Geobacillus strain SZN by using DEAE Sepharose Fast Flow column. Each step in the protein purification protocol: FT, flowthrough; W, washing unbound; E, elution and WAE, wash after elution, is separated by dashed lines. The gradient blue dashed line indicates the gradient concentration of $\mathrm{NaCl}$ in elution steps. Absorbance at $280 \mathrm{~nm}$ and aminoacylase activity was indicated by $(\boldsymbol{\square})$ and $(\boldsymbol{\Lambda})$, respectively. 
Table 1. Purification table of aminoacylase from Geobacillus strain SZN by Ion Exchange and Gel Filtration S-200 purification steps.

\begin{tabular}{cccccc}
\hline $\begin{array}{c}\text { Purification } \\
\text { step }\end{array}$ & $\begin{array}{c}\text { Total activity } \\
\text { (U) }\end{array}$ & $\begin{array}{c}\text { Total protein } \\
\text { content }(\mathbf{m g})\end{array}$ & $\begin{array}{c}\text { Specific } \\
\text { activity } \\
\text { (U/mg) }\end{array}$ & $\begin{array}{c}\text { Enzyme purity } \\
\text { (fold) }\end{array}$ & Yield (\%) \\
\hline Crude & 2130 & 450 & 4.73 & 1 & 100 \\
IEX $^{*}$ & 635 & 32.5 & 19.5 & 4.12 & 29.8 \\
${\text { S- } 200^{+}}^{3}$ & 352 & 5.3 & 66.4 & 14.04 & 16.53 \\
\hline
\end{tabular}

*Ion Exchange Chromatography

${ }^{+}$Gel Filtration Chromatography

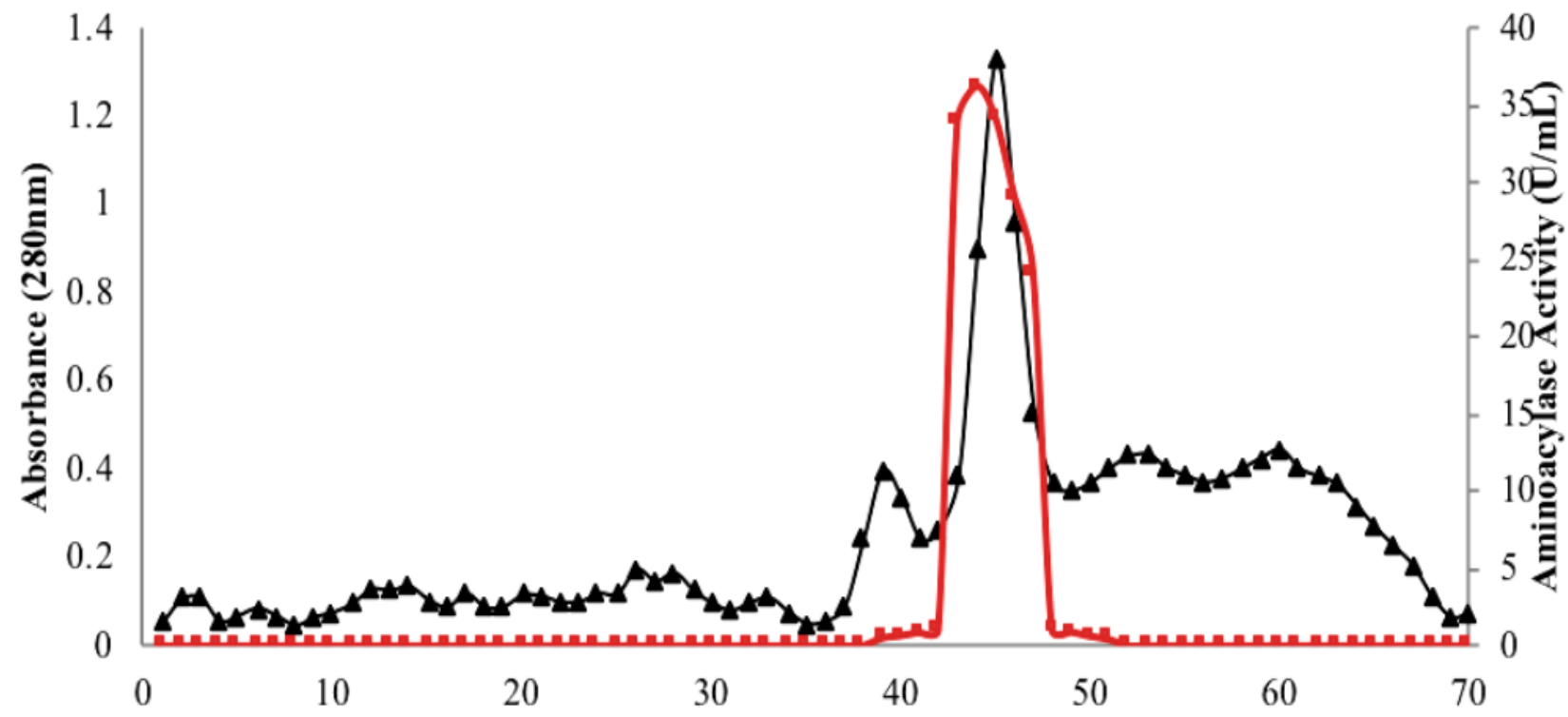

Fraction Number

Figure 2. Sephacryl S-200 Gel Filtration Chromatography of pooled fractions of protein from IEX. Absorbance at $280 \mathrm{~nm}$ and aminoacylase activity was indicated by ( $\mathbf{\Delta})$ and ( $\mathbf{\square})$, respectively.

\section{Thermal denaturation analysis}

Melting point analysis is an assessment of the dissociation-characteristics of protein secondary structure during heating. As the temperature raised, the helical structures begin to dissociate, leading to a rise in the absorbance intensity at 222 $\mathrm{nm}$. The temperature at which $50 \%$ of protein denatured is known as the melting point. The result was found to be parallel with its aminoacylase activity optimal temperature, where the enzyme started to lose $50 \%$ of the activity at above $80^{\circ} \mathrm{C}$ (Figure 5).

Effect of temperatures on aminoacylase activity and stability

The aminoacylase SZN relative activity was increased gradually from $37.6 \%$ to $100 \%$ at the temperatures from $30-60^{\circ} \mathrm{C}$ and decreased from $66 \%$ to $27 \%$ when increased temperatures from
70 to $90^{\circ} \mathrm{C}$. The aminoacylase SZN optimum temperature was detected at $60^{\circ} \mathrm{C}$ (Supplementary Material 1a). Stability of aminoacylase SZN from $5^{\circ} \mathrm{C}$ to $70^{\circ} \mathrm{C}$ was supported by its relative aminoacylase activity in Supplementary Material $1 \mathrm{~b}$ in which a significant lost (more than $50 \%$ ) was observed when the temperature increased to $80^{\circ} \mathrm{C}$ and above. At $70^{\circ} \mathrm{C}$, the stability of aminoacylase SZN was 73\% (Supplementary Material 1b).

Effect of exposure times at $60^{\circ} \mathrm{C}$ on aminoacylase $S Z N$ An in-depth investigation on the half-life of aminoacylase SZN was carried out at $60^{\circ} \mathrm{C}$. The half-life for the enzyme was deduced at $16 \mathrm{~h}$ (Supplementary Material 1c). Relative activity of aminoacylase SZN was reduced from $47 \%$ to $28 \%$ when incubated at 20,24, 28 and $32 \mathrm{~h}$. 
Table 2. Estimated percentage of secondary structures by using Perry Freeshell Software when protein was incubated at various temperatures.

\begin{tabular}{|c|c|c|c|c|c|c|c|c|c|c|}
\hline \multirow{2}{*}{$\begin{array}{c}\text { Secondary } \\
\text { structure }(\%)\end{array}$} & \multicolumn{10}{|c|}{ Temperature $\left({ }^{\circ} \mathrm{C}\right)$} \\
\hline & 10 & 20 & 30 & 40 & 50 & 60 & 70 & 80 & 90 & 100 \\
\hline$\alpha$-helix & 36.0 & 37.1 & 33.8 & 35.0 & 31.8 & 27.6 & 19.5 & 16.4 & 15.8 & 12.4 \\
\hline$\beta$-sheet & 17.2 & 16.9 & 18.9 & 16.3 & 19.3 & 23.3 & 27.8 & 27.7 & 31.5 & 33.1 \\
\hline Random & 31.0 & 30.5 & 31.5 & 31.5 & 32.2 & 33.2 & 35.7 & 36.2 & 36.5 & 37.6 \\
\hline
\end{tabular}

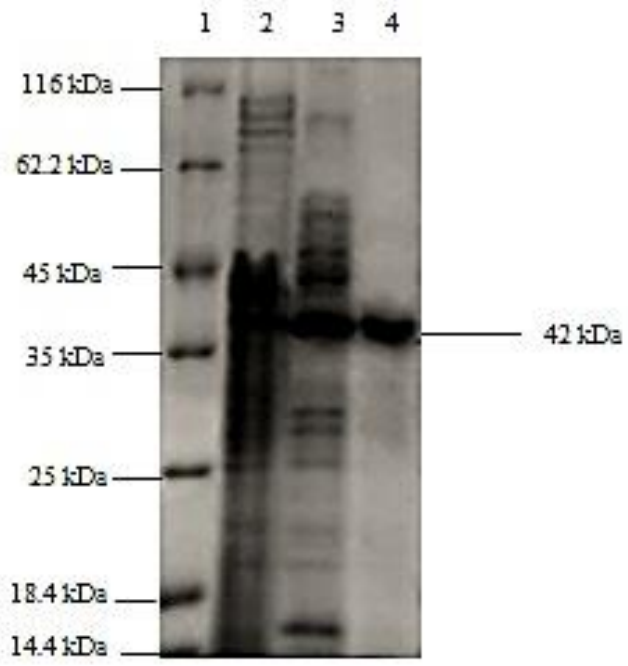

Figure 3. SDS-PAGE of aminoacylase SZN purification. Line 1, 2, 3, and 4 at top of the gel are samples from Unstained Protein Molecular Weight Marker (Fermentas, Canada), crude enzymes, IEX, and gel filtration, respectively. Components with their respective sizes $(\mathrm{kDa})$, found in standard protein marker are: $\beta$ galactosidase, 116.0; bovine serum albumin, 66.2; ovalbumin, 45.0; lactate dehydrogenase, 35.0; REase Bsp98I, 25.0; $\beta$-lactoglobulin, 18.4 and lysozyme, 14.4.

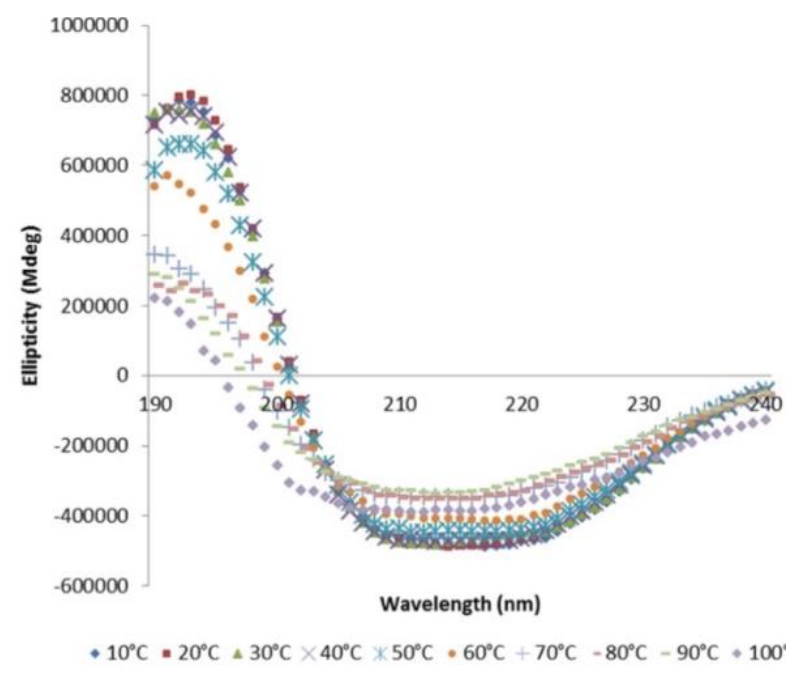

Figure 4. Far UV spectra of aminoacylase at various incubation temperatures.

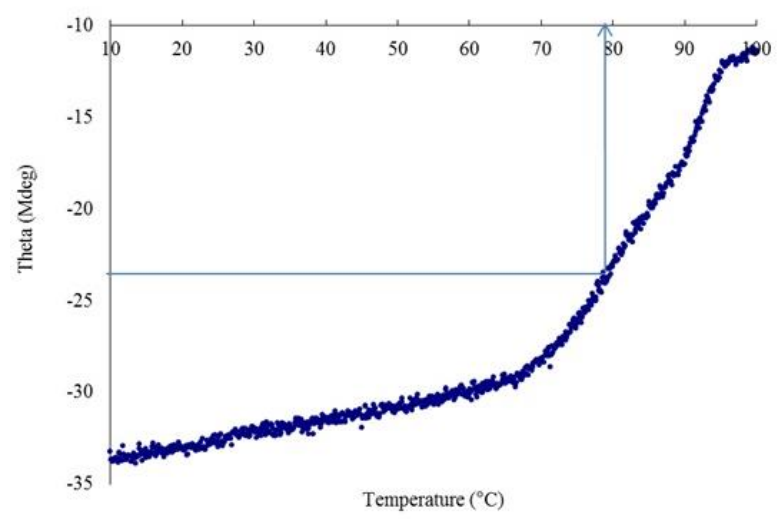

Figure 5. CD spectra for determination of thermal denaturation point of aminoacylase. A curve that indicates the transition state of the $\alpha$ helical structure was formed when the temperature raised from $70-80^{\circ} \mathrm{C}$. The temperature of $80^{\circ} \mathrm{C}$ at approximate midpoint of the sigmoidal curve has defined as thermal denaturation point of aminoacylase.

\section{Other characterization of thermostable aminoacylase $S Z N$}

Effect of $p H$ on aminoacylase activity and stability

In Supplementary Material 2a, the relative activity appeared low at $\mathrm{pH} 4(22.4 \%)$ and accelerated to optimum activity $(100 \%)$ when $\mathrm{pH}$ increased to 8 . However, the relative activity was significantly dropped after $\mathrm{pH} 9$ where the relative activity lost almost $80 \%$ at $\mathrm{pH} 12$, indicating that aminoacylase SZN works more efficiently at neutral $\mathrm{pH}$ environment. To test its stability in broad range of $\mathrm{pH}$, aminoacylase $\mathrm{SZN}$ was added to different buffers with different pHs. At $\mathrm{pH} 4$, the relative activity of the enzyme was $59 \%$. As the $\mathrm{pH}$ increased from 5 to 9 , the relative activity was restored to $81 \%$ at $\mathrm{pH} 9$ and $100 \%$ at $\mathrm{pH} 8$. Further increase of $\mathrm{pH} 10$ and $\mathrm{pH} 11$ had exhibited declination of the activity until $46 \%$ and totally lost at $\mathrm{pH} 12$.

\section{Effect of metal ions on aminoacylase activity}

Aminoacylase is a metalloenzyme, from M20 family that contained with at least one zinc ion for 
each subunit enzyme assisting in catalytic process. Treatment of aminoacylase SZN with $1 \mathrm{mM}$ and $10 \mathrm{mM} \mathrm{Zn}^{2+}$ did inhibit the activity, but strongly enhanced the thermostability, suggesting that additional $\mathrm{Zn}^{2+}$ may occur at the second metal binding site and induce a possible alteration in enzyme conformation to improve thermostability (Tanimoto et al., 2008). Our results showed that 1 $\mathrm{mM}$ metal ion reduced the aminoacylase activity, whereas the $10 \mathrm{mM} \mathrm{Cu}^{2+} \mathrm{Mg}^{2+}, \mathrm{Mn}^{2+}$ and $\mathrm{Na}^{+}$ increased the aminoacylase activity to 107,153 , 160 and 136\%, respectively (Supplementary Material 2c). We postulate that increased concentration of divalent ions, such as $\mathrm{Mg}^{2+}$ and $\mathrm{Mn}^{2+}$, may result in enhancement of activity, probably due to increased stability in enzymesubstrate and product complexes (Knape et al., 2017; Rahman et al., 2011).

\section{Effect of reducing and denaturing agents on aminoacylase activity}

Tween 20 and Triton X-100 demonstrated inhibition effects at concentrations of 5 and 10 $\mathrm{mM}$, where the relative activity was decreased from 90.7 to $85.8 \%$ and 73 to $66.4 \%$, respectively. At $10 \mathrm{mM}$, inhibition effects occurred in enzyme assay containing PMSF and SDS with its relative activity decreased to $91.6 \%$ and $85.4 \%$, respectively. Treatment of aminoacylase SZN with EDTA at 5 and $10 \mathrm{mM}$ did not inhibit the activity due to weak affinity of EDTA to $\mathrm{Zn}^{2+}$ (Tanimoto et al., 2008). This observation was supported by Sakanyan et al. (1993) who reported that the activity of aminoacylase from $B$. stearothermophilus can only be diminished at $50 \mathrm{mM}$ EDTA.

\section{DISCUSSION}

Aminoacylase enzyme is classified into the M20A family of metallopetidases, in which zinc is needed as an essential metal for catalytic activity (Lindner et al., 2003). Based on our reported data regarding amino acid sequence alignment of aminoacylase SZN with Pyrococcus horikoshii and several other species, the conserved regions of metal binding residues (Glu139 and Glu140), and catalytic residue (Arg261), were located at $\alpha$-helical structure (Adenan et al., 2018). Similarly,
Tanimoto and colleagues (2008) also revealed that the positions of metal binding site residues for Pyrococcus horikoshii were found at His106, Glu139, Glu140 and His164 and catalytic residues at H198 and A260. These findings are essential to understand the aminoacylase thermostability at structural point of view, as significant loss of $\alpha$ helical structure was observed at temperatures beyond $70^{\circ} \mathrm{C}$, and thus, preventing the metal binding and catalytic residues to be folded into its catalytically active conformation. Moreover, the melting point of aminoacylase SZN was recorded at $80^{\circ} \mathrm{C}$ (Figure 5), which was in agreement with the observation obtained from Supplementary Material 1a.

Thermostability of aminoacylase SZN may be assisted by existence of metal ion as ligand during catalysis reaction. This was supported by finding of $\alpha$-helix at the predicted catalytic and metal binding sites which is known to contribute to high portion of hydrogen bonds. More than $50 \% \alpha$ helix structure was predicted by using SOPMA (Deleage \& Geourjon, 1995) tool in Expasy for computation of secondary structures $\alpha$-helix, $\beta$ strand, and random coils, that is inferred to play a crucial role in maintaining the active conformation (Adenan et al., 2018). Native and active proteins are held together by a delicate balance of non-covalent forces among the secondary structures (hydrogen bonds, ion pairs, and hydrophobic and Van der Waals interactions). When high temperatures disrupt these noncovalent interactions, proteins become unfold and inactive.

The inhibitory effect of divalent ions, such as $\mathrm{Zn}^{2+}$ and $\mathrm{Ni}^{2+}$, was clearly observed on aminoacylase SZN. These ions have been reported to inhibit the proteolytic activities of elastase strain K (Rahman et al., 2011), ME-4 (Cheng et al., 2009) and PseA (Gupta et al., 2005) which also happened to be metalloproteases. The highest half-life of aminoacylase was reported by Hollingsworth (2002), who found that the stability of aminoacylase from Thermococcus litoralis was 25 $\mathrm{h}$ at $70^{\circ} \mathrm{C}$. Aminoacylase SZN can withstand a broad range of inhibitors and did not exhibit significant effects on its stability in detergent especially Tween 20 . Thus, the aminoacylase SZN can be potentially applied in industries, including pharmaceutical and food and beverage industries. Similar characteristics were reported for protease 
from Bacillus horikoshii, whereby the enzyme has shown excellent potential as an additive in feed and detergent industries due to its stability in SDS, oxidizing agents and organic solvents (Joo \& Choi, 2012). Characterization on aminoacylase SZN activity and stability in different $\mathrm{pHs}$ has shown that the enzyme optimum activity is ranging from $\mathrm{pH} 6-8$, similar to those optimum $\mathrm{pHs}$ for P. furiosus, Streptomyces mobaeraensis and Deinococcus Radiodurans R1 at pH 6.5 (Story et al., 2001), pH 7.5 (Koreishi et al., 2009) and pH 8 (Lin et al., 2007), respectively.

\section{CONCLUSION}

The wild-type aminoacylase SZN was purified in two steps, namely ion exchange and gel filtration chromatography, with approximately 14 -fold of specific activity compared to crude sample (Table 1). From this work, the structural properties of thermostable aminoacylase from Geobacillus sp. have unveiled the protein folding and unfolding mechanism involving $\alpha$-helical structure in high temperatures. Thus, the findings reported in this communication provide insights into characteristics, adaptation mechanism and behaviour of enzymes in various temperatures, especially at the estimated $\alpha$-helical structure of aminoacylase SZN active site, which is known to assist the enzyme stability at high temperatures.

\section{ACKNOWLEDGEMENTS}

We would like to thank The Ministry of Higher Education, Malaysia (RACE 2012-0145-102-62) for their financial aid in this project. Besides, we would like to dedicate our special appreciation to Malaysia Genome Institute for facilitating CD analysis.

\section{REFERENCES}

Adenan. S., Wong, C. F., Zain, H. H. M, Azziz, S. S. S. A., \& Rahman, R. N. Z. R. A. 2018. Isolation, identification and molecular characterization of thermophilic aminoacylase from Geobacillus sp. strain SZN. International Journal of Science Environment and Technology 7(5): 1483-1494.

Bradford, M. M. 1976. A rapid and sensitive method for the quantification of microgram quantities of protein utilizing the principles of protein-dye binding. Analytical Biochemistry 72: 248-254.

Cheng, M., Takenaka, S., Aoki, S., Murakami, S., \& Aoki, K. 2009. Purification and characterization of an eggshell membrane decomposing protease from Pseudomonas aeruginosa strain ME-4. Journal of Bioscience and Bioengineering 107: 373-378.

Deleage G. \& Geourjon. C. 1995. SOPMA: significant improvements in protein secondary structure prediction by concensus prediction from multiple allignments. Computer Applications in the Biosciences 11(6): 681-684.

Gupta, A., Roy, I., Khare, S. K., \& Gupta, M. N. 2005. Purification and characterization of a solvent stable protease from Pseudomonas aeruginosa PseA. Journal of Chromatography A 1069: 155-161.

Hollingsworth, E. J., Isupov, M. N., \& Littlechild, J. A. 2002. Crystallization and preliminary X-ray diffraction analysis of L-aminoacylase from the hyperthermophilic archaeon Thermococcus litoralis. Acta Crystallographica Section D Biological Crystallography 58(3): 507-510.

Joo, H.-S. \& Choi, J. W. 2012. Purification and characterization of a novel alkaline protease from Bacillus horikoshii. Journal of Microbiology and Biotechnology 22(1): 58-68.

Knape, M. J., Bertinetti, D., Ballez, M., Burghardt, N. C., Zimmermann, B., Kornev, A. P., \& Herberg, F. W. 2017. Divalent metal ions control activity and inhibition of protein kinases. Metallomics 9(11): 1576-1584.

Koreishi, M., Nakatani, Y., Ooi, M., Imanaka, H., Imamura, K., \& Nakanishi, K. 2009. Purification, characterization, molecular cloning, and expression of a new aminoacylase from Streptomyces mobaraensis that can hydrolyze $\mathrm{N}$ (Middle/Long)-chain-fatty-acyl-L-amino acids as well as NShort-chain-acyl-L-amino acids. Bioscience, Biotechnology, and Biochemistry 73 (9): 1940-1947.

Lin, L. L., Chen, M. H., Chien, H. C., Kan, S. C., Chen, C. C., Hu, H. Y., \& Hsu, W. H. 2007. Characterization of a bifunctional aminoacylase/carboxypeptidase from radioresistant bacterium Deninococcus radiodurans R1. Journal of Biotechnology 128: 322-334.

Lindner, H. A., Lunin, V. V, Alary, A., Hecker, R. and Cygler, M. 2003. Essential roles of zinc ligation and enzyme dimerization for catalysis in the aminoacylase-1/M20 Family. Journal of Biological Chemistry 278(45): 44496-44504.

Moore, S. \& Stein, W. H. 1948. Photometric ninhydrin method for use in the chromatography of amino acids. Journal of Biological Chemistry 176: 367-388.

Rahman, R. N. Z. R. A., Wong, C. F, Salleh, A. B., \& Basri, M. 2011. Role of $\alpha$-helical structure in organic solventactivated homodimer of elastase strain $\mathrm{K}$. International Journal of Molecular Sciences 12: 5797-5814.

Raussens, V., Ruysschaert, J. M., \& Goormaghtigh, E. 2003. Protein concentration is not an absolute prerequisite for the determination of secondary structure from circular dichroism spectra: a new scaling method. Analytical Biochemistry 319(1): 114-21.

Research \& Market. 2015. Amino acids market analysis by product (l-glutamate, lysine, methionine, threonine, tryptophan, leucine, iso-leucine, valine, glutamine, arginine, glycine, phenylalanine, tyrosine, citrulline, creatine, proline, serine), by source (plant-based \& animal-based), by application (animal feed, food \& dietary supplements \& pharmaceuticals) and segment forecasts to 2022. Amino acids market size, share, trends, global industry report, 2022. Retrieved from https://www.grandviewresearch. $\mathrm{com} /$ industry-analysis/amino-acids-market. 
Robinson, P. K. 2015. Enzymes: principles and biotechnological applications. Essays in Biochemistry 59: 1-41.

Sakanyan, V., Desmarez, L., Legrain, C., Charlier, D., Mett, I., Kochikyan, A., Savchenko, A., Boyen, A., Fulmagne, P., Pierard, A., \& Glansdorff, N. 1993. Gene cloning, sequence analysis, purification, and characterization of a thermostable aminoacylase from Bacillus strearothermophilus. Applied and Environmental Microbiology 59: 3878-3888.

Story, S. V., Grunden, A. M., \& Adams, M. W. 2001. Characterization of an aminoacylase from the hyperthermophilic archaeon Pyrococcus furiosus. Journal of Bacteriology 18: 4259-4268.

Tang, Z., Yu, J., Zhuo, Q., He, B., Wang, Z. \& Zhuo, H. 1995. Secondary structure circular of holo- and FT-Raman apoaminoacylase spectroscopy from prediction of aminoacylase. Journal of Biochemistry 709: 706-709.

Tanimoto, K., Higashi, N., Nishioka, M., Ishikawa, K., and Taya, M. 2008. Characterization of thermostable aminoacylase from hyperthermophilic archaeon Pyrococcus borikoshii. FEBS Journal 275: 1140-1149. 